University of Nebraska - Lincoln

DigitalCommons@University of Nebraska - Lincoln

Faculty Publications from the Harold W. Manter Laboratory of Parasitology

2010

\title{
Examination of Homalometron elongatum Manter, 1947 and Description of a New Congener from Eucinostomus currani Zahuranec, 1980 in the Pacific Ocean off Costa Rica
}

\author{
Jessica H. Parker \\ University of Southern Mississippi, jessica.h.parker@eagles.usm.edu \\ Stephen S. Curran \\ Gulf Coast Research Laboratory, stephen.curran@usm.edu \\ Robin M. Overstreet \\ Gulf Coast Research Laboratory, robin.overstreet@usm.edu \\ Vasyl V. Tkach \\ University of North Dakota, vasyl.tkach@und.nodak.edu
}

Follow this and additional works at: https://digitalcommons.unl.edu/parasitologyfacpubs

Part of the Parasitology Commons

Parker, Jessica H.; Curran, Stephen S.; Overstreet, Robin M.; and Tkach, Vasyl V., "Examination of Homalometron elongatum Manter, 1947 and Description of a New Congener from Eucinostomus currani Zahuranec, 1980 in the Pacific Ocean off Costa Rica" (2010). Faculty Publications from the Harold W. Manter Laboratory of Parasitology. 555.

https://digitalcommons.unl.edu/parasitologyfacpubs/555

This Article is brought to you for free and open access by the Parasitology, Harold W. Manter Laboratory of at DigitalCommons@University of Nebraska - Lincoln. It has been accepted for inclusion in Faculty Publications from the Harold W. Manter Laboratory of Parasitology by an authorized administrator of DigitalCommons@University of Nebraska - Lincoln. 


\title{
Examination of Homalometron elongatum Manter, 1947 and Description of a New Congener from Eucinostomus currani Zahuranec, 1980 in the Pacific Ocean off Costa Rica
}

\author{
Jessica H. Parker, ${ }^{1}$ Stephen S. Curran, ${ }^{1,3}$ Robin M. Overstreet, ${ }^{1}$ and Vasyl V. Tkach ${ }^{2}$ \\ ${ }^{1}$ The University of Southern Mississippi, Department of Coastal Sciences, 703 East Beach Drive, Ocean Springs, Mississippi \\ 39564, U.S.A. (e-mail: jessica.h.parker@eagles.usm.edu; stephen.curran@usm.edu; robin.overstreet@usm.edu) and \\ ${ }^{2}$ Department of Biology, University of North Dakota, 10 Cornell Street, Grand Forks, North Dakota 58202-9019, U.S.A. \\ (e-mail: vasyl.tkach@und.nodak.edu)
}

ABSTRACT: Homalometron elongatum is reexamined using heat-killed material that was not subjected to pressure during fixation from Gerres cinereus collected from San Juan Harbor, Puerto Rico, U.S.A. The new material is compared with some paratype specimens and differs by having a much less variable forebody length, and a median rather than submedian genital pore. Tegumental spines reportedly cover the anterior end of the body but we observed tegumental spines covering the entire body surface in both the paratype and new material. Homalometron lesliorum n. sp. is described from Eucinostomus currani from the Pacific coasts of Costa Rica and Nicaragua. The new species has 3 pairs of oral papillae surrounding the mouth and thus resembles 3 other congeners: H. elongatum, Homalometron carapevae, and Homalometron papilliferum. Homalometron lesliorum $\mathrm{n}$. sp. is distinguished from the 3 species by having the anterior extent of the vitelline follicles at or above the base of the ventral sucker, compared with posterior to the ventral sucker at the level of the seminal vesicle $(H$. elongatum) or further posterior at the posterior margin of the ovary (H. carapevae and $H$. papilliferum). The 4 species are further differentiated from one another by sucker width ratio, tegumental spine size and distribution, egg size, host preference, and biogeography. Comparison of nuclear ribosomal DNA (3' end of 18S, internal transcribed spacer [ITS]1, ITS2, and $5^{\prime}$ end of 28S) between H. elongatum and H. lesliorum n. sp. revealed 1 variable base $(n=162)$ at the $3^{\prime}$ end of $18 \mathrm{~S}, 12$ variable bases $(n=476)$ at ITS1, 10 variable bases $(n=310)$ at ITS2, and 11 variable bases $(n=1,325)$ at the $5^{\prime}$ end fragment of 28S. Nuclear ribosomal DNA from Homalometron pallidum and Homalometron armatum are included for further comparison with $H$. elongatum and H. lesliorum n. sp.

KEY WORDS: Homalometron elongatum, Homalometron lesliorum n. sp., Apocreadiidae, Trematoda, fishes, Gerres cinereus, Eucinostomus currani, Gerreidae, Puerto Rico, Costa Rica, Nicaragua.

Homalometron elongatum Manter, 1947 was described by Manter (1947) on the basis of material collected from the yellowfin mojarra, Gerres cinereus Walbaum, 1792, at Dry Tortugas, Florida, U.S.A. The species has since been reported from $G$. cinereus and the Atlantic spadefish, Chaetodipterus faber (Broussonet, 1782), off Puerto Rico, U.S.A. (Siddiqi and Cable, 1960); G. cinereus off Jamaica (Nahhas and Cable, 1964; Nahhas and Carlson, 1994); and $G$. cinereus and the jolthead porgy, Calamus bajonado (Bloch and Schneider, 1801), off Belize (Fischthal, 1977). Sogandares-Bernal (1959) reported H. elongatum from G. cinereus in Bimini, Bahamas and in the same publication reported a single specimen that lacked eggs from Eucinostomus californiensis (Gill, 1862), from the Pacific Ocean off Panama. That is the only report of the species from the Pacific Ocean.

During a survey of fish parasites from waters off the U.S. Virgin Islands and Puerto Rico, U.S.A., we collected specimens of H. elongatum from G. cinereus.

\footnotetext{
${ }^{3}$ Corresponding author.
}

During separate collection trips, we collected specimens belonging in Homalometron Stafford, 1904 from the Pacific flagfin mojarra, Eucinostomus currani Zahuranec, 1980, from the Pacific Ocean off Nicaragua and Costa Rica. Initially, we thought these Pacific specimens were conspecific with $H$. elongatum, but we noticed some morphological differences. Consequently, we examined nuclear ribosomal (r)DNA sequence variability among several species in Homalometron, including the Pacific specimens.

Homalometron elongatum has 6 papillae that project from the tegument around the mouth opening, but oral papillae were not reported in the original description. Bravo-Hollis and Manter (1957) later reported the presence of 3 pairs of papillae on the sides of the mouth in $H$. elongatum and illustrated that feature; however, the specimen illustrated was apparently not fixed well and the morphology of the figured papillae was inconsistent with that of heatkilled specimens. Morphological data we obtained from heat-killed specimens of $H$. elongatum we collected from the type host in Puerto Rico, U.S.A., is presented here because the type material was fixed 
Table 1. Hosts, localities, museum accession numbers, and GenBank numbers for digeneans in the present study.

\begin{tabular}{|c|c|c|c|c|c|}
\hline Homalometron spp. & Host & Locality & USNPC no. & GCRLM no. & GenBank no. \\
\hline H. lesliorum n. sp. & Eucinostomus currani & $\begin{array}{l}\text { Cuajiniquil, Guanacaste, } \\
\text { Costa Rica }\end{array}$ & $\begin{array}{l}102975 \text { (holotype); } \\
102976 \text { (1 paratype) }\end{array}$ & $\begin{array}{l}\text { GCRL 2970, } 2971 \\
\text { (2 paratypes) }\end{array}$ & $\begin{array}{r}\text { HM038041- } \\
\text { HM038042 }\end{array}$ \\
\hline H. elongatum & Gerres cinereus & $\begin{array}{l}\text { San Juan Harbor, } \\
\text { Puerto Rico, U.S.A. }\end{array}$ & 102977 (5 vouchers) & $\begin{array}{l}\text { GCRL 2972-2976 } \\
\text { (5 vouchers) }\end{array}$ & $\begin{array}{l}\text { HM038037- } \\
\text { HM038040 }\end{array}$ \\
\hline H. pallidum & Fundulus heteroclitus & $\begin{array}{l}\text { Stonington, Connecticut, } \\
\text { U.S.A. }\end{array}$ & $\begin{array}{c}102978-102980 \\
(3 \text { vouchers })\end{array}$ & $\begin{array}{l}\text { GCRL 2977-2979 } \\
\text { (3 vouchers) }\end{array}$ & $\begin{array}{l}\text { HM038043- } \\
\text { HM038044 }\end{array}$ \\
\hline H. armatum & Aplodinotus grunniens & $\begin{array}{l}\text { a. Reelfoot Lake, } \\
\text { Tennessee, U.S.A.; } \\
\text { b. Lake Chotard, } \\
\text { Mississippi, U.S.A. }\end{array}$ & 102981 (a. 1 voucher) & $\begin{array}{l}\text { GCRL } 2980 \\
\quad \text { (b. } 1 \text { voucher) }\end{array}$ & $\begin{array}{r}\text { HM038045- } \\
\text { HM038046 }\end{array}$ \\
\hline
\end{tabular}

with pressure. In addition, differences observed between rDNA gene fragments from Atlantic and Pacific forms, along with minor morphological differences, combine to support a distinct new species closely related to $H$. elongatum in the Pacific Ocean. That species is described here.

\section{MATERIALS AND METHODS}

Specimens of digeneans belonging in Homalometron were collected from gerreid hosts from 3 separate locations in 2003, 2007, and 2009. Infected hosts were collected using a casting net as follows: 4 specimens of E. currani were caught in a mangrove estuary connecting with the Pacific Ocean near Jiquilillo, Nicaragua $\left(12^{\circ} 45^{\prime} 51^{\prime \prime} \mathrm{N} ; 87^{\circ} 28^{\prime} 04^{\prime \prime} \mathrm{W}\right)$ on 15 July 2003; 6 specimens of $E$. currani were caught in the same location on 16 July 2003; 5 specimens of $E$. currani were caught from the Pacific Ocean off Cuajiniquil Beach in Guanacaste, Costa Rica $\left(10^{\circ} 56^{\prime} 05^{\prime \prime} \mathrm{N}\right.$; $85^{\circ} 42^{\prime} 17^{\prime \prime} \mathrm{W}$ ) on 13 July 2007; 2 additional specimens of E. currani were caught at the same location on 21 July 2007; and 3 specimens of $G$. cinereus were caught in San Juan Harbor, Puerto Rico, U.S.A. ( $18^{\circ} 27^{\prime} 32^{\prime \prime} \mathrm{N}$; $\left.66^{\circ} 07^{\prime} 01^{\prime \prime} \mathrm{W}\right)$, on 15-16 March 2009. For molecular comparison, we collected specimens of Homalometron pallidum Stafford, 1904 from the mummichog, Fundulus heteroclitus (Linnaeus, 1766), trapped off Stonington, Connecticut, U.S.A. $\left(41^{\circ} 20^{\prime} 22^{\prime \prime} \mathrm{N}\right.$; $71^{\circ} 52^{\prime} 46^{\prime \prime} \mathrm{W}$ ), on 4, 11 August 2004, and specimens of Homalometron armatum (MacCallum, 1895) from gillnetted freshwater drum, Aplodinotus grunniens Rafinesque, 1819 at Reelfoot Lake, Obion County, Tennessee, U.S.A. $\left(36^{\circ} 23^{\prime} 08^{\prime \prime} \mathrm{N}\right.$; $\left.89^{\circ} 21^{\prime} 27^{\prime \prime} \mathrm{W}\right)$, on 18 October 2003 and from Lake Chotard, Issaquena County, Mississippi, U.S.A. $\left(32^{\circ} 34^{\prime} 28^{\prime \prime} \mathrm{N}\right.$; $\left.91^{\circ} 02^{\prime} 40^{\prime \prime} \mathrm{W}\right)$, on 29 January 2001 . We did not record the number of uninfected hosts examined during these collections so no prevalence data are presented. All fish were dissected while fresh and intestinal digeneans were rinsed with $0.75 \%$ saline solution. Some digeneans were immediately killed in hot tap water and then fixed and stored in $5 \%$ neutral buffered formalin solution. Others were placed directly in $95 \%$ ethanol for DNA extraction. Those stored in formalin solution were later stained following the protocol of Curran et al. (2007). Type and voucher specimens of all species of Homalometron collected during this study are deposited at the United States National Parasite Collection (USNPC), Beltsville, Maryland, U.S.A., and at the Gulf Coast Research Laboratory Museum (GCRLM), Ocean Springs, Mississippi, U.S.A. (Table 1). Paratype material of $H$. elongatum was examined at the Harold W. Manter Laboratory, Nebraska State Museum (HWML), Lincoln, Nebraska, U.S.A. Measurements are presented in micrometers as the mean (when possible) followed by the range in parentheses.

Genomic DNA was isolated from individual ethanol-fixed specimens of the Costa Rican form $(n=2)$, H. elongatum ( $n$ $=4), H$. pallidum $(n=2)$, and H. armatum $(n=2)$ using Qiagen DNAeasy tissue kit (Qiagen, Inc., Valencia, California, U.S.A.) following the instructions provided or according to Tkach and Pawlowski (1999). DNA fragments measuring approximately 2,500 base pairs long comprising the $3^{\prime}$ end of $18 \mathrm{~S}$ nuclear rDNA gene, internal transcribed spacer (ITS) region ( $=$ ITS $1+5.8 \mathrm{~S}+\mathrm{ITS} 2)$, and the $5^{\prime}$ end of the $28 \mathrm{~S}$ gene (including variable domains D1-D3) were amplified from the extracted DNA by polymerase chain reactions (PCR) on an Eppendorf master gradient thermal cycler or a Peltier gradient thermal cycler (specimens of $H$. elongatum) using forward primer ITSF (5'CGCCCGTCGCTACTACCGATTG- $\left.3^{\prime}\right)$ or S20T2 (5'GGTAAGTGCAAGTCATAAGC- $\left.3^{\prime}\right)$ and reverse primer 1500R (5'-GCTATCCTGAGGGAAACTTCG-3'). These PCR primers and multiple internal primers were used in sequencing reactions. The internal forward primers were: digl2 (5'-AAGCATATCACTAAGCGG-3'), 300F (5'CAAGTACCGTGAGGGAAAGTTG- $\left.3^{\prime}\right)$, and 900F (5'CCGTCTTGAAACACGGACCAAG- $3^{\prime}$ ). The internal reverse primers used were: 300R (5'-CAACTTTCCCTCACGGTACTTG-3'), Digl2r (5'-CCGCTTAGTGATATGCTT$3^{\prime}$ ), and ECD2 (5'-CTTGGTCCGTGTTTCAAGACGGG$\left.3^{\prime}\right)$. The PCR reactions were performed following the protocols described by Tkach et al. (2003).

The resulting PCR products were purified with Qiagen Qiaquick $^{\mathrm{TM}}$ columns, cycle sequenced using ABI BigDye ${ }^{\mathrm{TM}}$ chemistry (Applied Biosystems, Inc., Carlsbad, California, U.S.A.), alcohol precipitated, and run on either an ABI Prism $3100^{\mathrm{TM}}$ automated capillary DNA sequencer or an ABI 3130 Genetic Analyzer ${ }^{\mathrm{TM}}$. Contiguous sequences were assembled using Sequencher ${ }^{\mathrm{TM}}$ (GeneCodes Corp., Ann Arbor, Michigan, U.S.A., Version 4.7) and submitted to the GenBank (Table 1). Contiguous sequences from the 4 replicates of $H$. elongatum, 2 replicates of the Costa Rican form, 2 replicates of $H$. pallidum, and 2 replicates of $H$. armatum were aligned using Clustal $\mathrm{W}$ module incorporated in BioEdit 7.0.9. (Tom Hall, Ibis Biosciences, Carlsbad, California, U.S.A., 2007). 
Homalometron elongatum Manter, 1947 (Figs. 1-3)

\section{Supplemental data}

On the basis of measurements from 19 heat-killed specimens and observations from 7 paratypes. Body elongated, 3,017 (1,797-3,564) long, 349 (214-424) wide. Body tegument entirely covered by small spines. Oral sucker subterminal, 202 (156-223) long, 200 (162-218) wide, with 3 pairs of opposing papillae projecting from tegument surrounding mouth opening. Prepharynx elongated, 155 (130-187) long, with posterior end enveloping anterior end of pharynx; pharynx 88 (68-102) long, 89 (65-99) wide, partially surrounded by gland cells. Esophagus 172 (99-219) long. Ventral sucker 169 (128-187) long, 168 (134-185) wide. Ratio of oral sucker length to the ventral sucker length 1:0.83 (1:0.76-0.88). Ratio of oral sucker width to ventral sucker width 1:0.84 (1:0.790.88 ). Ceca bifurcating approximately $2 / 3$ of distance between oral and ventral suckers and approximately $1 / 2$ distance between pharynx and ventral sucker, ending blindly 167 (67-270) from posterior body end. Postcecal space representing 2-8\% of body length. Forebody 767 (585-910) long, representing 23-33\% of body length, containing diffuse eyespot remnants between mouth and ventral sucker.

Testes subspherical and elongated, tandem; anterior testis 290 (165-352) long, 210 (145-246) wide; posterior testis 318 (193-391) long, 220 (151-262) wide. Intertesticular space $50(0-108)$ long. Posttesticular space 608 (176-854), representing 20-25\% of body length. Cirrus sac absent. Male terminal genitalia free in parenchyma, consisting of seminal vesicle, pars prostatica, and ejaculatory duct; seminal vesicle median or submedian, lying dorsal to ventral sucker and extending into hindbody, 172 (136-221) long, 86 (74-105) wide, opening into spindle-shaped prostatic region, 45-57 long, 31-34 wide; pars prostatica opening into slender elongated ejaculatory duct, 105-163 long, 10 wide; ejaculatory duct merging with muscular elongated female duct forming a muscular dorsoventrally flattened hermaphroditic duct, 43 long (1 laterally mounted specimen), 28-37 wide; hermaphroditic duct opening through medial genital pore, immediately anterior to ventral sucker.

Ovary subspherical, 148 (94-173) long, 128 (82153) wide, median or submedian, approximately $1 / 2$ the distance between ventral sucker and anterior testis. Distance between ovary and anterior testis 340 (151-435). Seminal receptacle club-shaped, dorsal to and extending anterior to ovary, opening into oviduct near posterior margin of ovary. Laurer's canal muscular, approximately 20 in diameter, not fully observed. Vitellarium consisting of 1 confluent field of large follicles in hindbody; anterior extent at a level 78 (11-151) posterior from the posterior margin of the ventral sucker; extending posteriorly to the posterior body end; follicles dorsal and intercecal in ovarian region, and dorsal, ventral, lateral, and intercecal in postovarian region; follicles occupying intertesticular space when present. Ootype immediately postovarian. Uterus intercecal, extending between ootype and ventral sucker in ventral aspect of hindbody; distal portion a muscular metraterm. Eggs 82 (74-91) long, 47 (42-57) wide.

Excretory vesicle I-shaped, terminating in the posttesticular space 54 (9-122) from the posterior margin of the posterior testis; excretory pore subterminal on dorsal surface.

\section{Taxonomic summary}

Type host: Gerres cinereus (Walbaum, 1792).

Type locality: Tortugas, Florida, U.S.A.

Host for material studied: G. cinereus.

Locality and date of collection: San Juan Harbor, Puerto Rico, U.S.A. $\left(18^{\circ} 27^{\prime} 32^{\prime \prime} \mathrm{N}\right.$; $\left.66^{\circ} 07^{\prime} 01^{\prime \prime} \mathrm{W}\right)$, on 15-16 March 2009.

Site of infection: Intestine.

Specimens deposited: 5 voucher specimens USNPC no. $102977 ; 5$ voucher specimens GCRLM nos. 2972-2976.

Additional specimens examined: H. elongatum (HWML no. 187, 7 paratypes).

\section{Remarks}

Our specimens of $H$. elongatum conform to the diagnoses for Homalometron and Apocreadiidae Skrjabin, 1942 given by Cribb (2005) and agree with most important aspects of Manter's (1947) description of the species. Specifically in our specimens and Manter's (1947) description, 1) the prepharynx envelops the anterior end of the pharynx, 2) the esophagus is longer than the pharynx, 3) the ceca extend almost to the posterior end of the body, 4) the anterior extent of the vitelline follicles lies in the hindbody and exists between the ventral sucker and ovary, and 5) the eggs are the same size. Our specimens differ from those in the original description by not having a flattened body but flattening 

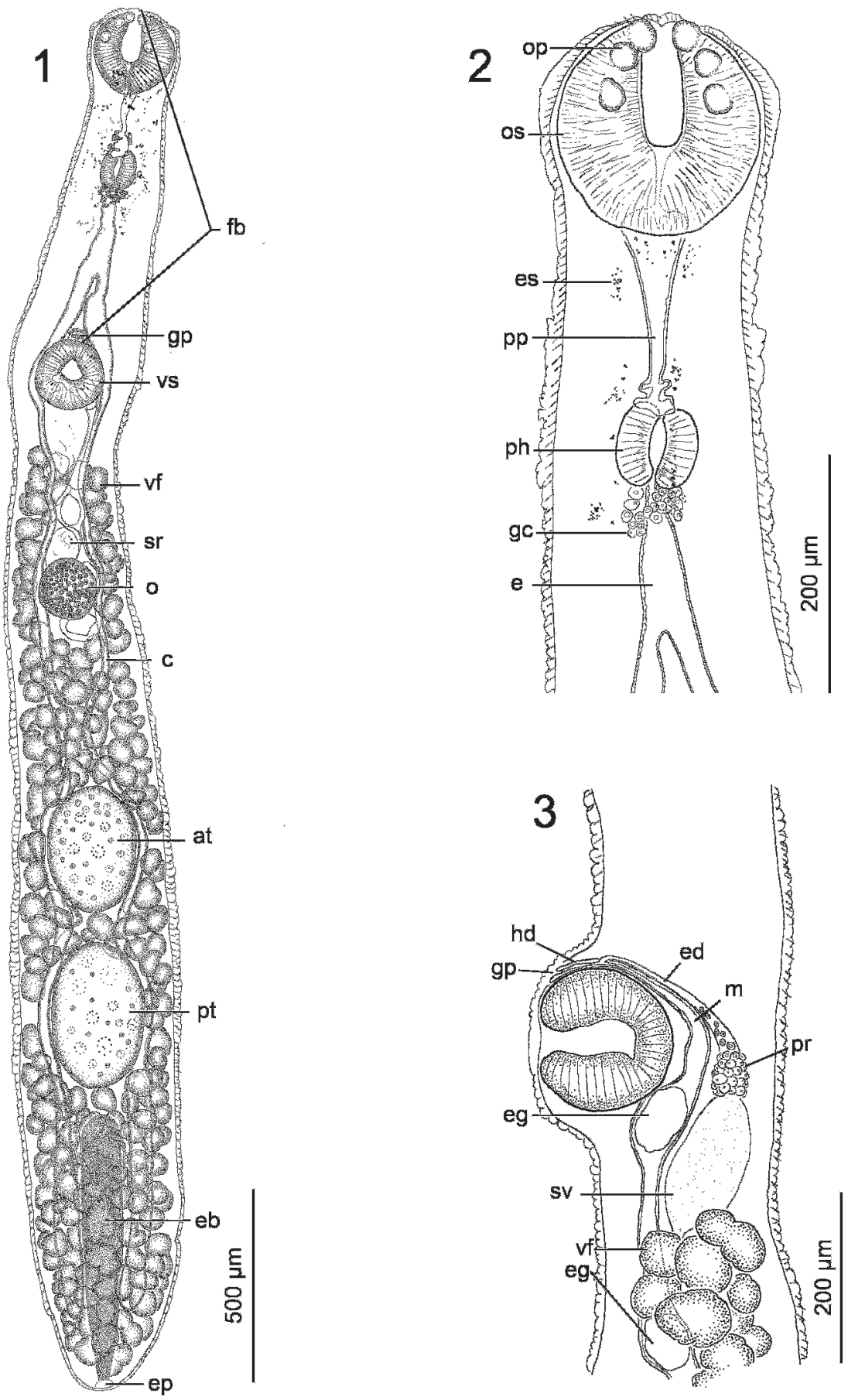

Figures 1-3. Homalometron elongatum from Gerres cinereus from San Juan Harbor, Puerto Rico, U.S.A. 1. Ventral view of whole mount. 2. Anterior end. 3. Lateral view of ventral sucker, male and female genitalia. (Abbreviations: at, anterior testis; c, ceca; e, esophagus; eb, excretory bladder; ed, ejaculatory duct; eg, egg; ep, excretory pore; es, eye spots; fb, forebody; gc, gland cells; gp, genital pore; hd, hermaphroditic duct; m, metraterm; o, ovary; op, oral papillae; os, oral sucker; ph, pharynx; pp, prepharynx; pr, prostatic region; pt, posterior testis; sr, seminal receptacle; sv, seminal vesicle; vf, vitelline follicle; vs, ventral sucker.) 
appears to be an artifact of specimen preparation. Additionally, we observed a forebody length of 23$33 \%$ of body length in our specimens compared with $20-50 \%$ of body length reported by Manter (1947). Manter (1947) reported that the genital pore was submedian, but it was median in all of our specimens. His submedian genital pore may have been another artifact caused by flattening. Finally, Manter (1947) reported the presence of small spines covering the tegument on the anterior end of the body but we observed small spines covering the entire body surface including the dorsal and ventral surfaces but excluding the vicinity around the ventral sucker and mouth in our specimens. We examined 7 of Manter's paratype specimens (HWML no. 187) and observed small tegumental spines in the vicinity of the testes and some spines in the posttesticular region in addition to prominent small tegumental spines in the anterior region of the body. The spines in the posterior half of the body were difficult to detect, and we attribute our ability to observe them to having better optics available to us than to Manter (1947).

\section{Homalometron lesliorum n. sp. (Figs. 4-6)}

\section{Description}

On the basis of measurements from 5 specimens and additional observations from 2 poorly fixed specimens. Body elongated, 2,107 (1,628-2,675) long, 348 (234-424) wide. Body tegument covered by small spines. Oral sucker subterminal, 172 (125207) long, 188 (162-213) wide, with 3 pairs of opposing papillae projecting from tegument surrounding mouth opening. Prepharynx elongated, 89 (45-125), with posterior end enveloping anterior end of pharynx; pharynx 72 (45-91) long, 70 (51-85) wide, partially surrounded by gland cells. Esophagus 153 (116-190) long. Ventral sucker 169 (125-199) long, 172 (131-199) wide. Ratio of oral sucker length to the ventral sucker length 1:0.99 (1:0.90-1.05). Ratio of oral sucker width to ventral sucker width 1:0.91 (1:0.81-0.98). Ceca bifurcating approximately $2 / 3$ of distance between oral and ventral suckers and approximately $1 / 2$ between pharynx and ventral sucker, ending blindly 131 (102-159) from posterior body end. Postcecal space representing 5.6-6\% body length. Forebody 519 (304-674) long, representing $23-31 \%$ body length, containing diffuse eyespot remnants between mouth and ventral sucker.

Testes subspherical and elongated, tandem; anterior testis 217 (116-296) long, 159 (125-190) wide; posterior testis 263 (139-379) long, 168 (134-193) wide. Intertesticular space 34 (3-74) long. Posttesticular space 485 (111-933), representing 6-50\% of body length. Cirrus sac absent. Male terminal genitalia free in parenchyma; consisting of sacshaped seminal vesicle, pars prostatica, and ejaculatory duct; seminal vesicle median or submedian, dorsal ventral sucker and extending into hindbody, (151-199) long, (88-142) wide, opening into spindleshaped prostatic region, 57 long, 28 wide in 1 lateral specimen; ejaculatory duct merging with muscular elongated female duct forming a muscular dorsoventrally flattened hermaphroditic duct, 60 long (1 laterally mounted specimen), 34 wide in the holotype; hermaphroditic duct opening through medial genital pore, immediately anterior to ventral sucker.

Ovary nearly globular, 136 (85-182) long, 123 (88-145) wide, median to submedian, approximately $1 / 2$ the distance between ventral sucker and anterior testis. Distance between ovary and anterior testis 113 (31-168). Seminal receptacle flask-shaped, dorsal to and extending anterior to ovary, opening into oviduct near posterior margin of ovary. Laurer's canal present, not fully observed. Vitellarium consisting of one confluent field of large follicles in hindbody and extending approximately 35 (14-85) into the level of the ventral sucker end. Follicles dorsal and intercecal in ovarian region and dorsal, ventral, lateral, and intercecal posterior to ovarian complex; follicles usually occupying intertesticular space. Uterus originating from region of ootype and extending anteriorly to the level of the ventral sucker. Eggs 77-91 long, 48-65 wide.

Excretory vesicle I-shaped, terminating in posttesticular region, 67 (34-134) from posterior end of posterior testis; excretory pore subterminal on dorsal surface.

\section{Taxonomic summary}

Type host: Eucinostomus currani Zahuranec, 1980.

Type locality: Pacific Ocean off Cuajiniquil in Guanacaste, Costa Rica $\left(10^{\circ} 56^{\prime} 05^{\prime \prime} \mathrm{N} ; 85^{\circ} 42^{\prime} 17^{\prime \prime} \mathrm{W}\right)$.

Collection dates: 13, 21 July 2007.

Other locality and collection dates: Mangrove estuary (connecting with Pacific Ocean) adjacent to Jiquilillo, Nicaragua $\left(12^{\circ} 45^{\prime} 51^{\prime \prime} \mathrm{N}, 87^{\circ} 28^{\prime} 04^{\prime \prime} \mathrm{W}\right) 15$, 16 July 2003.

Site of infection: Intestine.

Specimens deposited: Holotype USNPC no. 102975 and 1 paratype USNPC nos. 102976; 2 paratypes GCRLM no. 2970-2971. 

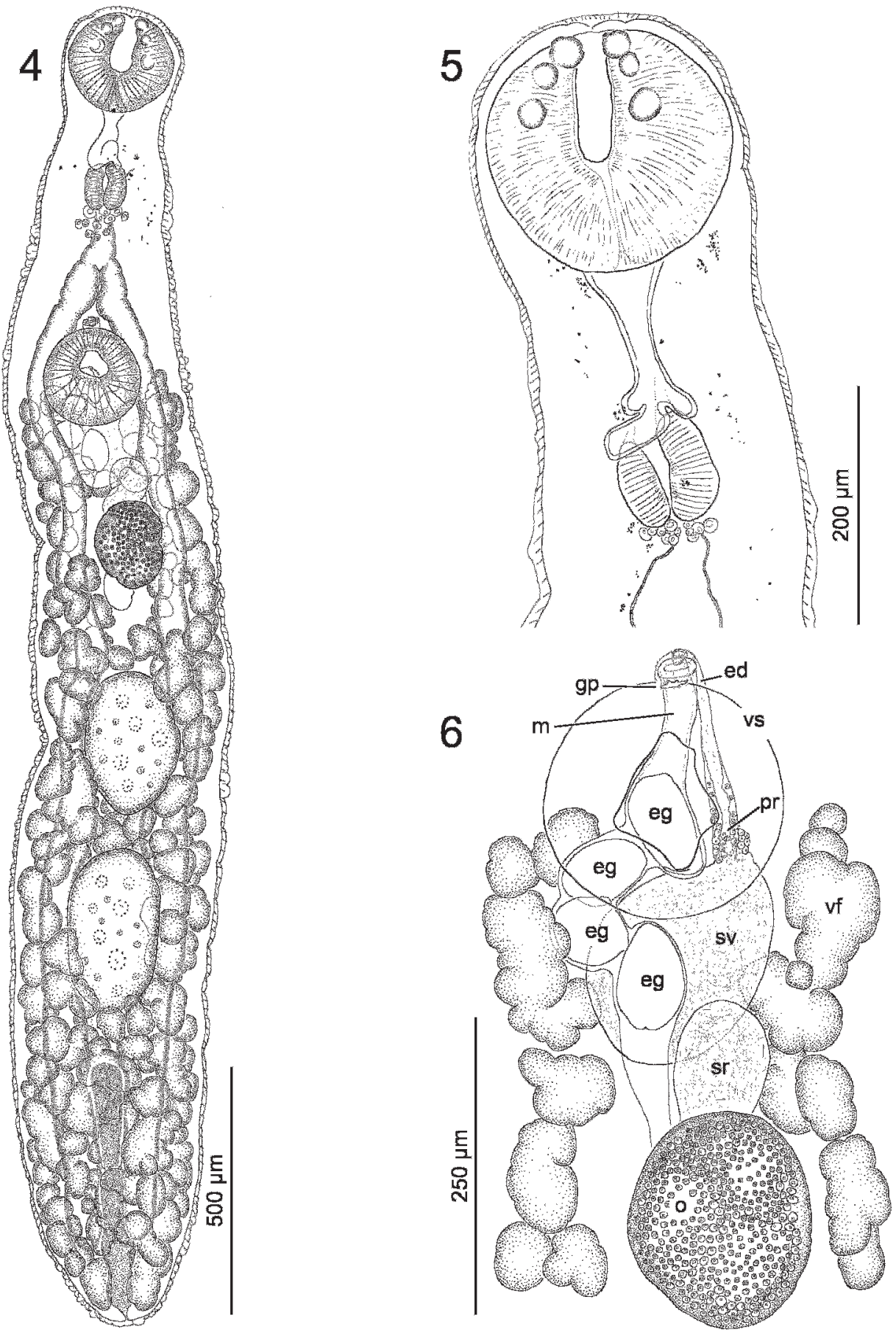

Figures 4-6. Homalometron lesliorum n. sp. from Eucinostomus currani from Cuajiniquil Beach, Guanacaste, Costa Rica. 4. Ventral view of whole mount. 5. Anterior end. 6. Ventral view of male and female terminal genitalia. (Abbreviations: ed, ejaculatory duct; eg, egg; gp, common genital pore; m, metraterm; o, ovary; pr, prostatic region; sv, seminal vesicle; vf, vitelline follicle; vs, ventral sucker.) 
Table 2. Number of variable sites with $(\%)$ based on pairwise comparison of 162-base-long $3^{\prime}$ end of $18 S$ nuclear ribosomal DNA region (above diagonal) and number of variable sites with $(\%)$ based on pairwise comparison of 476 base-pair complete ITS1 nuclear ribosomal DNA (below diagonal) among 4 studied species of Homalometron.

\begin{tabular}{lccc}
\hline Digenean species & H. lesliorum n. sp. & H. elongatum & H. pallidum \\
\hline H. lesliorum n. sp. & - & $1(0.6 \%)$ & $2(1.2 \%)$ \\
H. elongatum & $12(2.5 \%)$ & - & $1(0.6 \%)$ \\
H. pallidum & $30(6.3 \%)$ & $25(5.2 \%)$ & - armatum \\
H. armatum $*$ & $26(5.5 \%)$ & $22(4.6 \%)$ & $1.2 \%)$ \\
\hline
\end{tabular}

* The complete ITS1 region had only 475 base pairs in H. armatum.

Comparative material examined: Homalometron carapevae Amato, 1983 (HWML no. 21376, 3 paratypes).

Etymology: This species is named to honor Scott Leslie Rodgers and his grandson Charles Leslie Parker.

\section{Remarks}

Homalometron lesliorum n.sp. conforms to the diagnoses for Homalometron and Apocreadiidae given by Cribb (2005). The new species has an elongated body and 3 pairs of oral papillae and therefore is most similar to a small group of species that includes $H$. elongatum, $H$. carapevae Amato, 1983 from the Brazilian mojarra, Eugerres brasilianus (Cuvier, 1830), a coastal gerreid in Brazil, and Homalometron papilliferum (Szidat, 1956) from the creole perch, Percichthys trucha (Cuvier and Valenciennes, 1833), a freshwater percichthyid in Argentina. Homalometron lesliorum, $H$. elongatum, and $H$. carapevae all have similarly sized eggs (ranging from 74-92 $\mu \mathrm{m}$ long and 40-65 $\mu \mathrm{m}$ wide), and small tegumental spines that cover the entire body. Homalometron papilliferum has slightly larger eggs than the other 3 species $(77-110 \mu \mathrm{m}$ long by 44 $65 \mu \mathrm{m}$ wide), and scalelike spines that cover the anterior region of the body (Ostrowski de Nuñez et al., 2000). The 4 species are most easily differentiated from each other by distribution of the vitelline follicles. Homalometron lesliorum has vitelline follicles that extend anteriorly well into the level of the ventral sucker. Homalometron elongatum has vitelline follicles that extend anteriorly into the region of the seminal vesicle but never as far as the ventral sucker. Both $H$. carapevae and $H$. papilliferum have vitelline follicles that extend anteriorly to the ovarian level. Of the 4 species, only $H$. papilliferum lacks vitelline follicles between the testes. The species may be further distinguished by sucker width ratio. Both $H$. lesliorum and $H$. elongatum have a sucker width ratio of approximately $1: 0.9 ; H$. papilliferum has a sucker width ratio of 1:0.7-1.2 (see Ostrowski de Nuñez et al., 2000), and $H$. carapavae has a sucker width ratio of 1:1.4-1.6 (see Amato, 1983).

\section{MOLECULAR RESULTS}

The aligned sequenced fragments comprising the $3^{\prime}$ end of $18 \mathrm{~S}$ gene, complete ITS region, and $5^{\prime}$ end of $28 \mathrm{~S}$ gene from the 4 species examined varied slightly in length. The sequences from $H$. lesliorum and $H$. elongatum were 2,432 base pairs long. Those from $H$. pallidum and $H$. armatum measured 2,431 base pairs long. No intraspecific sequence variability was observed among replicates. The $3^{\prime}$ end of the 18S gene measured 162 bases in each of the 4 species examined and was very conserved among the 4 species (see Table 2). The $5.8 \mathrm{~S}$ region was 158 base pairs long and was identical in all 4 species examined. Pairwise comparison of complete ITS1, complete ITS2, and $5^{\prime}$ end of the $28 \mathrm{~S}$ gene fragment among the 4 examined species of Homalometron revealed a great amount of variation (see Tables 2,3). Homalometron lesliorum and $H$. elongatum were the most similar genetically among the species examined and differed from each other at a total of $34(1.4 \%)$ of 2,432 aligned bases.

\section{DISCUSSION}

Ribosomal DNA is useful for helping to distinguish between digenean species, particularly morphologically similar species or those that are cryptic (morphologically indistinguishable) (see Tkach et al., 2000; Snyder and Tkach, 2001; Olson and Tkach, 2005). Nolan and Cribb (2005) advocated that the ITS region of the rDNA, excluding its conservative $5.8 \mathrm{~S}$ region, was the most useful portion for differentiating between congeneric digenean species. These authors comprehensively reviewed taxonomic studies that used ITS rDNA to distinguish between digenean species in 19 families. Very few studies have examined the ITS region of apocreadiid species. 
Table 3. Number of variable sites with (\%) based on pairwise comparison of 310-base-pair complete ITS2 nuclear ribosomal DNA region (above diagonal) and number of variable sites with $(\%)$ based on pairwise comparison of 1,325-base-pair fragment at the $5^{\prime}$ end of $28 S$ nuclear ribosomal DNA gene (below diagonal) among 4 studied species of Homalometron.

\begin{tabular}{lcccc}
\hline Digenean species & H. lesliorum n. sp. & H. elongatum & H. pallidum & H. armatum \\
\hline H. lesliorum n. sp. & - & $10(3.2 \%)$ & $27(8.7 \%)$ & $24(7.7 \%)$ \\
H. elongatum & $11(0.8 \%)$ & - & $26(8.4 \%)$ & $25(8.0 \%)$ \\
H. pallidum & $33(2.5 \%)$ & $34(2.6 \%)$ & - & $15(4.8 \%)$ \\
H. armatum* & $38(2.9 \%)$ & $43(3.2 \%)$ & $29(2.2 \%)$ & - \\
\hline
\end{tabular}

* The complete ITS2 region had 311 base pairs in H. armatum.

Lo et al. (2001) reported that the ITS2 region for the apocreadiid Schistorchis zancli Hanson, 1953 showed no variation in its 266 nucleotides between 2 populations separated by over $6,000 \mathrm{~km}$. In the only other study involving ITS data from apocreadiids, Pérez-Ponce de León et al. (2008) reported that the 405-base-pair-long ITS1 region in 3 species of Crassicutis Manter, 1936 diverged between 1.4\% and $12 \%$. These authors corroborated those data by showing that a 789-base-pair-long nucleotide fragment of the $28 \mathrm{~S}$ gene diverged by 4-6\% (PérezPonce de León et al., 2008). This study of Homalometron represents the first for which the entire ITS region is reported for a member of Apocreadiidae, and it included 4 species. The ITS region measured 944 nucleotides in length in each of the 4 species studied; however, in H. armatum, the ITS1 was 1 base pair shorter and the ITS2 was 1 base pair longer than in the other species (see Tables 2, 3). Among the 4 species of Homalometron, ITS1 basepair divergence ranged between $2.5 \%$ and $6.3 \%$, and ITS2 base-pair divergence ranged between $3.2 \%$ and $8.7 \%$ (Tables 2, 3). Base-pair divergence at the 28S region ranged between $0.8 \%$ and $3.2 \%$ (see Table 3 ), and complemented the data from the ITS region in our study. Of the 4 species we examined, $H$. lesliorum and $H$. elongatum exhibited the most genetic similarity, but since all divergences were between ranges previously reported for congeneric apocreadiids and other digeneans, it may be concluded that our molecular results strongly support the recognition of $H$. lesliorum as a new species (e.g., Nolan and Cribb, 2005; Snyder and Tkach, 2007; Tkach and Snyder, 2007; Pérez-Ponce de León et al., 2008; Blasto-Costa et al., 2009). Relative sequence similarity across the studied rDNA fragments combined with their similar overall morphology and use of gerreid hosts suggests that the 2 species are very closely related. We consider $H$. elongatum a widespread parasite of fishes throughout the Carib- bean Sea, whereas $H$. lesliorum occurs in the eastern Pacific Ocean off Central America. We suspect that the single mature but nonovigerous specimen of $H$. elongatum reported from Eucinostomus californiensis from the Pacific coast of Panama by SogandaresBernal (1959) may have in fact been a specimen of $H$. lesliorum or perhaps another undescribed species of Homalometron with oral papillae. The specimen was neither illustrated nor deposited in a lending museum, and Sogandares-Bernal (1959) did not describe the anterior extent of the vitelline follicles.

The anterior extent of the vitelline follicles is an important species-level feature within Apocreadiidae. Some species in Homalometron have the anterior extent of the vitelline follicles slightly anterior to the ventral sucker base (e.g., H. lesliorum, H. pallidum, H. armatum, Homalometron pseudopallidum Martorelli, 1986, Homalometron dowgialloi Dyer, Williams and Bunkley-Williams, 1992). Most species in Homalometron consistently have the anterior extent of the vitelline follicles more posterior in the body (e.g., H. elongatum, H. carapevae, H. papilliferum, Homalometron senegalense Fischthal and Thomas, 1972, Homalometron galaicus (Sanmartín, Alvarez, Quinteiro, and Paniagua, 1995), Homalometron moraveci Bray, Justine and Cribb, 2007). The identifications of some forms that have the anterior extent of the vitelline follicles in the hindbody such as $H$. pallidum from the Gulf of Mexico need to be reevaluated (Sparks, 1958; Nahhas and Short, 1965; Vidal-Martínez et al., 2001).

\section{ACKNOWLEDGMENTS}

We are grateful to several people who were instrumental in facilitating collections during this study. These included Guillermo H. Sánchez, Eric E. Pulis, and Michael J. Andres (all from The University of Southern Mississippi); Lesber Salazar and José Bernardo Ortega González (both from Universidad 
Internacional de la Integración de América Latina, Chinandega, Nicaragua); Paul R. Cislo (Yale University); Daniel R. Brooks (University of Toronto); Róger Blanco Segura and Briceño Duvalier (both from Ministerio Del Ambiente y Energía Sistema nacional De Areas De Conservación: Área De Conservación Guanacaste, Costa Rica); Mark A. Grace and Christopher T. Gledhill (both National Marine Fisheries Service, Pascagoula, Mississippi, U.S.A., Laboratory); Scott D. Snyder (University of Nebraska at Omaha) and Michael A. Barger (Peru State College). In addition, we thank Jean A. Jovonovich-Alvillar for conducting some molecular procedures and Kristine N. White for advice on molecular analysis (both from The University of Southern Mississippi). We thank Janine N. Caira (University of Connecticut) and the University of Tennessee, Martin Reelfoot Lake Research and Teaching Center for facilitating dissections. We thank Scott L. Gardner (HWML) for allowing S.S.C. to examine specimens. This material is based on work supported by the National Science Foundation under grant no. 0529684, and by the United States Department of Commerce, National Oceanographic and Atmospheric Administration award no. NA08NOS4730322.

\section{LITERATURE CITED}

Amato, J. F. R. 1983. Digenetic trematodes of percoid fishes of Florianópolis, Southern Brasil. Homalometridae, Lepocreadiidae, and Opecoelidae, with the description of seven new species. Revista Brasileira de Biologia 43:73-98.

Blasto-Costa, I., J. A. Balbuena, A. Kostadinova, and P. D. Olson. 2009. Interrelationships of the Haploporinae (Digenea: Haploporidae): a molecular test of the taxonomic framework based on morphology. Parasitology International 58:263-269.

Bravo-Hollis, M., and H. W. Manter. 1957. Trematodes of marine fishes of Mexican waters. X. Thirteen Digenea, including nine new species and two new genera, from the Pacific Coast. Proceedings of the Helminthological Society of Washington 24:35-48.

Cribb, T. H. 2005. Family Apocreadiidae Skrjabin, 1942. Pages 621-639 in A. Jones, R. A. Bray, and D. I. Gibson, eds. Keys to the Trematoda. Vol. 2. CAB International and The Natural History Museum, London.

Curran, S. S., R. M. Overstreet, and V. V. Tkach. 2007. Phylogenetic affinities of Plagiocirrus Van Cleave and Mueller, 1932 with the description of a new species from the Pascagoula River, Mississippi. Journal of Parasitology 93:1452-1458.

Fischthal, J. H. 1977. Some digenetic trmatodes of marine fishes from the Barrier Reef and Reef Lagoon of Belize. Zoologica Scripta 6:81-88.
Lo, C. M., J. A. T. Morgan, R. Galzin, and T. H. Cribb. 2001. Identical digeneans in coral reef fishes from French Polynesia and the Great Barrier Reef (Australia) demonstrated by morphology and molecules. International Journal for Parasitology 31:1573-1578.

Manter, H. W. 1947. The digenetic trematodes of marine fishes of Tortugas, Florida. American Midland Naturalist 38:257-416.

Nahhas, F. M., and R. M. Cable. 1964. Digenetic and Aspidogastrid trematodes from marine fishes of Curaçao and Jamaica. Tulane Studies in Zoology 11: 169-228.

Nahhas, F. M., and K. Carlson. 1994. Digenetic trematodes of marine fishes of Jamaica, West Indies. Hofstra University Marine Laboratory, Ecological Survey of Jamaica Publication 2:1-60.

Nahhas, F. M., and R. B. Short. 1965. Digenetic trematodes of marine fishes from Apalachee Bay, Gulf of Mexico. Tulane Studies in Zoology 12:39-50.

Nolan, M. J., and T. H. Cribb. 2005. The use and implications of ribosomal DNA sequencing for the discrimination of digenean species. Advances in Parasitology 60:103-163.

Olson, P. D., and V. V. Tkach. 2005. Advances and trends in the molecular systematics of the parasitic Platyhelminthes. Advances in Parasitology 60:166-243.

Ostrowski de Nuñez, M., N. Brugni, and G. Viozzi. 2000. Polylekithum percai $\mathrm{n}$. sp. (Trematoda: Allocreadiidae) from Percichthys trucha (Perciformes: Percichthydae) in Patagonia, Argentina, and a redescription of Homalometron papilliferum (Szidat, 1956) n. comb. Systematic Parasitology 47:51-57.

Pérez-Ponce de León, G., U. Razo-Mendivil, R. RosasValdez, B. Mendoza-Garfias, and H. Mejía-Madrid. 2008. Description of a new species of Crassicutis Manter, 19636, parasite of Cichlasoma Beani Jordan (Osteichthyes:Cichlidae) in Mexico, based on morphology and sequences of the ITS1 and 28S ribosomal RNA genes. Journal of Parasitology 94:257-263.

Siddiqi, A. H., and R. M. Cable. 1960. Scientific survey of Puerto Rico and the Virgin Islands: digenetic trematodes of marine fishes of Puerto Rico. The New York Academy of Sciences 17:257-328.

Snyder, S. D., and V. V. Tkach. 2001. Phylogenetic and biogeographical relationships among some holarctic frog lung flukes (Digenea: Haematoloechidae). Journal of Parasitology 87:1433-1440.

Snyder, S. D., and V. V. Tkach. 2007. Neosychnocotyle maggiae, n. gen., n. sp. (Platyhelminthes: Aspidogastrea) from freshwater turtles in northern Australia. Journal of Parasitology 93:399-403.

Sogandares-Bernal, F. 1959. Digenetic trematodes of marine fishes from the Gulf of Panama and Bimini, British West Indies. Tulane Studies in Zoology 7:71117.

Sparks, A. K. 1958. Some digenetic trematodes of fishes of Grand Isle, Louisiana. Proceedings of the Louisiana Academy of Sciences 20:71-82.

Tkach, V. V., D. T. J. Littlewood, P. D. Olson, J. M. Kinsella, and Z. Swiderski. 2003. Molecular phylogenetic analysisof the Microphalloidea Ward, 1901 (Trematoda: Digenea). Systematic Parasitology $56: 1-15$. 
Tkach, V. V., and J. Pawlowski. 1999. A new method of DNA extraction from the ethanol-fixed parasitic worms. Acta Parasitologica 44:147-148.

Tkach, V. V., J. Pawlowski, and V. P. Sharpilo. 2000. Molecular and morphological differentiation between species of the Plagiorchis vespertilionis group (Digenea, Plagiorchiidae) occurring in European bats, with a re-description of $P$. vespertilionis (Müller, 1780). Systematic Parasitology 47:9-22.
Tkach, V. V., and S. D. Snyder. 2007. Aptorchis megacetabulus $\mathrm{n}$. sp. (Platyhelminthes: digenea) from the northern long-necked turtle, Chelodina Rugosa (Pleurodira: Chelidae), in Australia. Journal of Parasitology 93:404-408.

Vidal-Martínez, V. M., M. L. Aguirre-Macedo, T. Scholz, D. González-Solís, and E. F. Mendoza-Franco. 2001. Atlas of the Helminth Parasites of Cichlid Fish of Mexico. Academia, Prague, Czech Republic. 165 pp. 